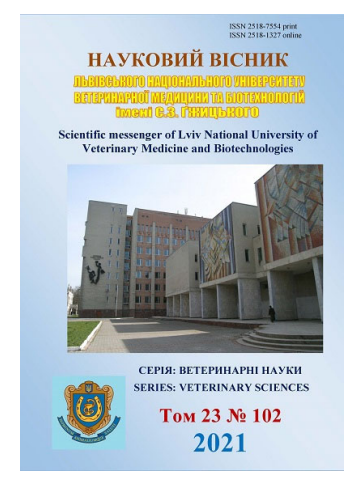

Науковий вісник Яьвівського національного університету ветеринарної медицини та біотехнологій імені С.3. Гжицького. Серія: Ветеринарні науки

\author{
Scientific Messenger of Lviv National University \\ of Veterinary Medicine and Biotechnologies. \\ Series: Veterinary sciences
}

UDC 619:591.437:636.8

\title{
Pathomorphology of cat pancreas under chronic pancreatitis
}

\author{
O. V. Kovalchuk, L. P. Goralskyi, I. M. Sokulskyi \\ Polissia National University, Zhytomyr, Ukraine
}

Article info

Received 05.04.2021 Received in revised form 06.05 .2021

Accepted 07.05.2021

Polissia national university, Staryj Boulevard, 7, Zhytomyr, 10002, Ukraine. Tel.: +38-097-785-73-20 E-mail: sokulskiy_1979@ukr.net
Kovalchuk, O. V., Goralskyi, L. P., \& Sokulskyi, I. M. (2021). Pathomorphology of cat pancreas under chronic pancreatitis. Scientific Messenger of Lviv National University of Veterinary Medicine and Biotechnologies. Series: Veterinary sciences, 23(102), 87-92. doi: $10.32718 /$ nvlvet10213

The paper deals with studying the pathomorphology of cat pancreas under chronic pancreatitis. This paper is a component of a research mix of the Department of Anatomy and Histology, it goes under the title "The development, morphology and histo-chemistry of animal organs in health and in disease", (state registration number № 0120U100796). A pancreas is an azygos parenchymatous organ which refers to the endoexocrine glands, includes exocrine and endocrine pancreas, is involved in the processes of digestion and regulation of carbohydrate metabolism, protein metabolism and lipid exchange in tissues. Pancreatic juice, which is rich in enzymes (trypsin, lipase, amylase), is produced in an exocrine pancreas, and hormones (insulin, somatostatin, glucagon (vasoactive intestinal polypeptide), pancreatic polypeptide) are produced in endocrine pancreas. This galand is involved in the process of digestion while producing digestive enzymes, which get into the duodenum and hydrolyze practically all parts of feeds which enter the body. It is located in an abdominal cavity, anatomically connected with a stomach, liver and duedenum. It has been found that pathomorphological changes in pancreas under chronic pancreatits manifest themselves depending on the disease stage and are revealed by insignificant progress of the pathological process. Herewith, morphological parameters of pancreas width and length in cats under chronical pancreatitis did not significantly change, but these indices tended to decrease. Its absolute weight in cats under chronical pancreatitis, as compared with clinically healthy cats, did not change and equalled $9.12 \pm 2.03 \mathrm{~g}$. But pancreas relative weight in sick cats increased by $1.4(P \leq 0.01)$ and equalled $0.51 \pm 0.08 \%$, as compared with control $0.38 \pm 0.06 \%$. Under histological analysis of pancreas histology specimen stained with hematoxylin Corazzi and eosin, some distortion in a microscopic structure of a pancreas was observed, it manifested itself in thickening of interparticle tissue-connective layers which spread like desmogenous bands. Some destructive changes in acini in exocrinal pancreas, which manifested themselves in losing their characteristic form, were noticed. The cytoplasm of such acinous cells was in a state of plasmorrhexis, the pycnosis was observed.

Key words: morphology, microscopic structure, pancreas, morphological parameters, swelling, acini, necrosis, stagnation, focuses of haemorrhages, hyalinosis.

\section{Патоморфологія підшлункової залози котів за хронічного панкреатиту}

\author{
О. М. Ковальчук, Л. П. Горальський, І. М. Сокульський
}

Поліський начіональний університет, м. Житомир, Украӥна

\footnotetext{
У статті наведено результати дослідження патоморфології підшлункової залози котів за хронічного панкреатиту. Наукова стаття є фрагментом науково-дослідної тематики кафедри анатомії і гістології "Розвиток, морфологія та гістохімія органів тварин у нормі та при патології” (номер державної реєстрації № 0120U100796). Підилункова залоза - непарний паренхіматозний орган належить до залоз зміманої секреції, включає в себе екзокринну і ендокринну частини, бере участь у травленні та регуляціі вуглеводного, білкового та жирового обмінів у тканинах. В екзокринній частині продукується панкреатичний сік, багатий травними ферментами (трипсин, ліпаза, амілаза тощо), в ендокринній - виробляються гормони (інсулін, соматостатин, глюкагон (вазоактивний інтестинальний поліпептид), панкреатичний поліпептид). Залоза бере участь у травленні, виробляючи травні
} 
ферменти, щзо надходять в дванадиятипалу кимку $і$ здійснюють гідроліз практично усіх частин корму, щзо надходить в організм. Вона розташована в черевній порожнині тіла, анатомічно пов'язана зі шлунком, печінкою і дванадцятипалої кишкою. 3 'ясовано, шо патоморфологічні зміни у підшлунковій залозі за хронічного панкреатиту проявляються залежно від фази захворювання та визначаються незначним перебігом патологічного процесу. При цьому морфологічні параметри довжини та ширини часток підилункової залози у котів за хронічного панкреатиту майже не змінювалися, однак спостерігалася тенденція до зменшення таких показників. Ї̈ абсолютна маса у котів за хронічного перебігу панкреатиту, порівняно з клінічно здоровими тваринами, майже не змінювалася і становила 9,12 \pm 2,03 г. Проте відносна маса підилункової залози хворих котів достовірно (P $\leq 0,01)$ збільшилась у 1,34 раза та становила 0,51 \pm 0,08 \%, порівнюючи з контролем 0,38 \pm 0,06 \%. За гістологічного дослідженнями гістопрепаратів підшлункової залози, забарвлених гематоксиліном Карачі та еозином, встановлено порушення мікроскопічної будови підилунковоі залози, щчо проявлялись потовщенням міжчасточкових сполучнотканинних прошарків, які розгалужувались у вигляді сполучнотканинних тяжів. Виявляли деструктивні зміни ацинусів у екзокринній частині, які проявлялися втратою характерної їм форми. Цитоплазма таких ацинарних клітин була у стані плазморексису, спостерігався пікноз їх ядер.

Ключові слова: морфологія, мікроскопічна будова, підилункова залоза, морфологічні параметри, набряк, ацинуси, некроз, стаз, вогнищеві крововиливи, гіаліноз.

\section{Вступ}

Хвороби органів травлення часто трапляються у ветеринарній практиці (Gushchin et al., 2018). Стан здоров'я собак та котів багато в чому залежить від функціональної діяльності травної системи, повноцінна функція якої своєю чергою залежить від активності підшлункової залози і печінки (Horalskyi et al., 2013). Підшлункова залоза є морфологічно складною залозою зовнішньої і внутрішньої секреції (Horalskyi et al., 2016; Didenko, 2017). Вона продукує панкреатичний сік, який відіграє значну роль у процесі травлення і регуляції вуглеводного, білкового та жирового обмінів у тканинах (Horalskyi et al., 2021). Робота підшлункової залози підпорядковується нейрогуморальної регуляції, ii патологія призводить до серйозних наслідків для організму людей та тварин (Zinenko \& Tverdohleb, 2020). Порушення екзокринної функції підшлункової залози внаслідок запальних процесів різної етіології може служити причиною ендогенної інтоксикації з багатокомпонентним системним запальним синдромом, який нерідко супроводжується летальним наслідком у результаті поліорганної неспроможності.

Актуальність теми. Панкреатит є одним із захворювань шлунково-кишкового тракту тварин, яке характеризується ураженням підшлункової залози (Berehovenko \& Zinenko, 2008; Vasiliev \& Urazaev, 2009). Це запальне захворювання підшлункової залози, іiї значної частини, що відповідає за вироблення травних ферментів в ацинарних клітинах та проявляється запаленням паренхіми - екзо- та ендокриної частин залози (Dybuch, 2008; Horalskyi et al., 2013).

У більшості випадків запалення підшлункової залози котів у загальній клінічній практиці залишається невиявленим через відсутність чіткої специфічної симптоматики (Katten, 2013).

Нині у ветеринарній медицині прийнято класифікувати панкреатит на гострий та хронічний, залежно від ступеня зрілості патологічних змін в тканині підшлункової залози (Zinenko \& Tverdohleb, 2017).

За характером запалення патоморфологічно виділяють геморагічний, гнійний, дифузний, паренхіматозний, флегмонозний панкреатити. При гострому панкреатиті, після усунення етіологічного чинника, запальний процес та всі викликані ним зміни в органі практично повністю зворотні (Kravchenko \& Bobrova,
2018). При хронічному панкреатиті спостерігається більш тривале запалення паренхіми органа 3 формуванням незворотних гістологічних змін, а саме некроз, фіброз, іноді атрофія (Kravchenko \& Bobrova 2018; Tuboltseva \& Zhukov, 2018). Крім цього, може бути важка форма захворювання, яка супроводжується розвитком панкреонекрозу і системних ускладнень (Tymoshenko, 2007). Така патологія є найбільш актуальною проблема у кішок в зв'язку 3 анатомічною будовою протоків підшлункової залози, які відкриваються на дуже близькій відстані від вивідного протока жовчного міхура і при різних антиперистальтичних рухах дванадцятипалої кишки. При цьому трапляється різке виділення жовчі в протоку підшлункової залози, що провокує його запалення.

Однак, як показують дані літератури, можуть виникати значні труднощі як в діагностиці, внаслідок невизначеності даних анамнезу, отриманих від власника і відсутності симптомів, так і при лікуванні даної патології (Filonenko \& Klimov, 2009). Водночас панкреатит має характерні патологоанатомічні зміни. Необхідно розуміти, що остаточний діагноз можливо встановити тільки шляхом виконання біопсії даного органа та проведення патогістологічних досліджень. Тому патоморфологічне дослідження гістоархітектоніки підшлункової залози тварин за панкреатиту є актуальним питанням ветеринарної медицини.

\section{Матеріал і методи досліджень}

Дослідження проводили на кафедрі анатомії і гістології факультету ветеринарної медицини Поліського національного університету. Робота є фрагментом комплексної наукової програми відповідної кафедри на тему: "Розвиток, морфологія та гістохімія органів тварин у нормі та при патології”, номер державної реєстрації-0120U100796.

В роботі використовувались анатомічні, гістологічні морфометричні та статистичні методи дослідження.

Матеріалом для досліджень була підшлункова залоза статевозрілих котів.

Патологоанатомічний розтин трупів котів проводили методом часткової евісцерації у загальноприйнятій послідовності (Zon et al., 2009).

Для мікроскопічних досліджень відібраний матеріал фіксували в $10 \%$ водному розчині нейтрального 
формаліну та рідині Карнуа з подальшою швидкою заливкою матеріалу в парафін за загальноприйнятою методикою (Horalsky et al., 2019).

Гістологічні зрізи товщиною 7-10 мкм фарбували гематоксиліном і еозином.

Фотографування гістологічних зрізів здійснювали відеокамерою CAM V-200, вмонтованою у мікроскоп. Цифровий матеріал статистично обробляли за допомогою комп'ютерної програми “Excel” 3 пакету "Microsoft Office 2003".

\section{Результати та їх обговорення}

Хвороби підшлункової залози у котів важко діагностувати через значну невизначеність їх клінічних проявів та недостатню кількість діагностичних методів. Однак хронічне запалення протоків підшлункової залози нерідко виявляють при розтині у статевозрілих котів (Raraty et al., 2004; Xenoulis, 2015).

Перебіг патологічного процесу за хронічного панкреатиту відрізняється від гострого лише тим, що періоди загострення асоціюються 3 субклінічним перебігом (Raraty et al., 1998).

Встановлено, що загострення перебігу хронічного панкреатиту часто проявляється у тварин, водночас його зазвичай приймають як гострий (Anderson et al., 1995). До того ж напади хвороби за субклінічного процесу часто призводять до повної втрати екзокринної паренхіми залози, яка заміщується фіброзною тканиною (Westermarck \& Wiberg, 2003).

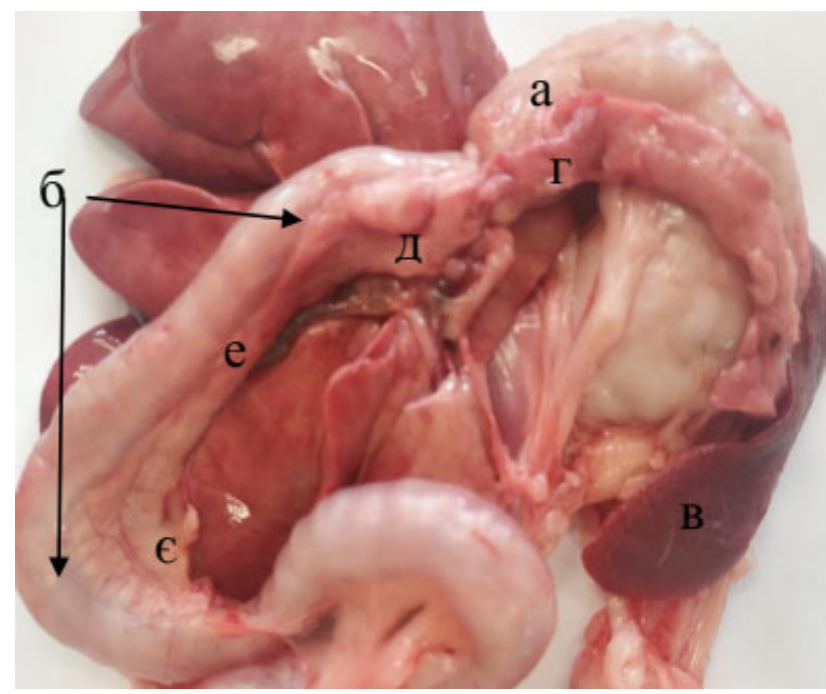

Рис. 1. Макроскопічна будова підшлункової залози кота за хронічного перебігу панкреатиту:

a - пілорична частина шлунка; б - дванадцятипала кишка; в - селезінка; г - ліва частка залози; д - тіло залози; е - права частка залози; $\epsilon$ - гачкоподібний згин. Макропрепарат

Лінійні параметри - довжина та ширина часток підшлункової залози - у хворих тварин за хронічного панкреатиту майже не змінювалися, лише спостерігалася тенденція до незначного зменшення вищезазначених лінійних промірів органа (табл. 1).
Згідно з науковими дослідженнями О. П. Тимошенко та Ю. М. Бусела (2009), підшлункова залоза у собак за хронічного панкреатиту блідого кольору, не збільшена, iї тканина ущільнена (Tymoshenko \& Busel, 2009).

За результатами наших досліджень, у хворих котів за перебігу хронічного панкреатиту підшлункова залоза набувала блідо-сірого кольору, дещо зменшувалась у розмірах, проте була щільнішої консистенції (рис. 1). В окремих тварин великі вивідні протоки залози були розширені та містили різноманітної величини сіруватого кольору камінці.

Притім підшлункова залоза мала типову часточкову будову не на всьому проміжку. Її ацинарний рисунок був згладжений, панкреатоцити дисоційовані та не визначалась зональність їх цитоплазми. Міжчасточкова сполучна тканина була потовщена. У залозистій тканині виявлялись тяжі, які розгалужені у глибину часточок. Стінки вивідних проток органа гіалізовані. Острівці Лангерганса подовжені, нерівних контурів та не чітко були відмежовані від оточуючої ацинарної тканини, їх кількість зменшена.

За результатами органометричних досліджень, абсолютна маса підшлункової залози у котів за хронічного перебігу панкреатиту, якщо порівняти з клінічно здоровими тваринами $(9,0 \pm 0,98$ г), майже не змінювалася і становила 9,12 $\pm 2,03$ г. Проте відносна маса залози у хворих тварин достовірно $(\mathrm{P} \leq 0,01)$ збільшилась у 1,34 раза і становила $0,51 \pm 0,08 \%$, порівнюючи 3 контролем $0,38 \pm 0,06 \%$ (табл. 1 ).

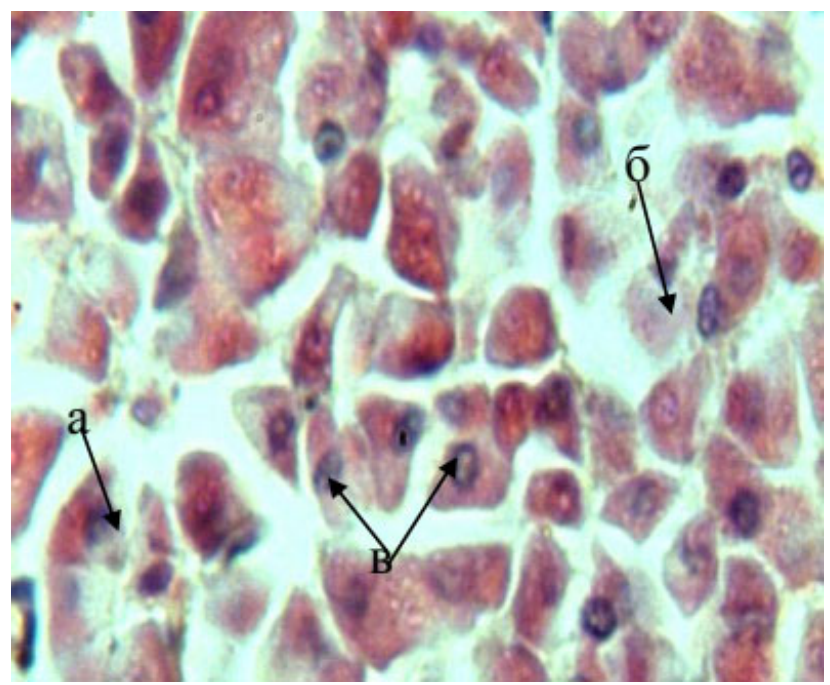

Рис. 2. Фрагмент мікроскопічної будови підшлункової залози котів за хронічного панкреатиту: а - дискомплексація ацинусів; б - каріолізис; в - цитоплазмі включення у вигляді краплин. Гематоксилін Караці та еозин. Х. 600

За мікроскопічного дослідження гістологічних препаратів, забарвлених гематоксиліном та еозином, підшлункової залози котів за хронічного панкреатиту виявили порушення гістоархітектоніки органа. Такі виражені зміни проявлялися дискомплексацією ацинусів екзокринної частини ПЗ. За цитологічного ана- 
лізу ацинарних панкреатоцитів їх зональність цитоплазми не прослідковувалась, такі клітини погано сприймали забарвлення та містили у своїй цитоплазмі включення у вигляді краплин. Ядра таких клітин пе- ребували у стані каріолізису. Разом з тим часто виявлялись ядра, які певною мірою ще зберегли свою структуру та розміщувались у центрі цитоплазми панкреатоцитів (рис. 2).

\section{Таблиця 1}

Органометричні показники підшлункової залози котів за хронічного панкреатиту $(\mathrm{M} \pm \mathrm{m})$

\begin{tabular}{lcc}
\hline \multicolumn{1}{c}{ Показники } & \multicolumn{2}{c}{ Групи тварини } \\
\cline { 2 - 3 } & клінічно здорові, $\mathrm{n}=6$ & $9,12 \pm 2,03$ \\
\hline Абсолютна маса підшлункової залози, г & $9,0 \pm 0,98$ & $0,51 \pm 0,08^{* *}$ \\
Відносна маса підшлункової залози, \% & $0,38 \pm 0,06$ & $14,2 \pm 1,16^{*}$ \\
Довжина підшлункової залози, см & $14,98 \pm 0,99$ & $1,30 \pm 0,92$ \\
Ширина лівої частки, см & $1,45 \pm 0,17$ & $1,53 \pm 0,71$ \\
Ширина середньої частки, см & $1,88 \pm 0,08$ & $1,18 \pm 0,78$ \\
Ширина правої частки, см & $1,27 \pm 0,09$ &
\end{tabular}

Примітка: *- $P \leq 0,05 ; * *-P \leq 0,01 ; * * *-P \leq 0,001$ порівняно з клінічно здоровими тваринами

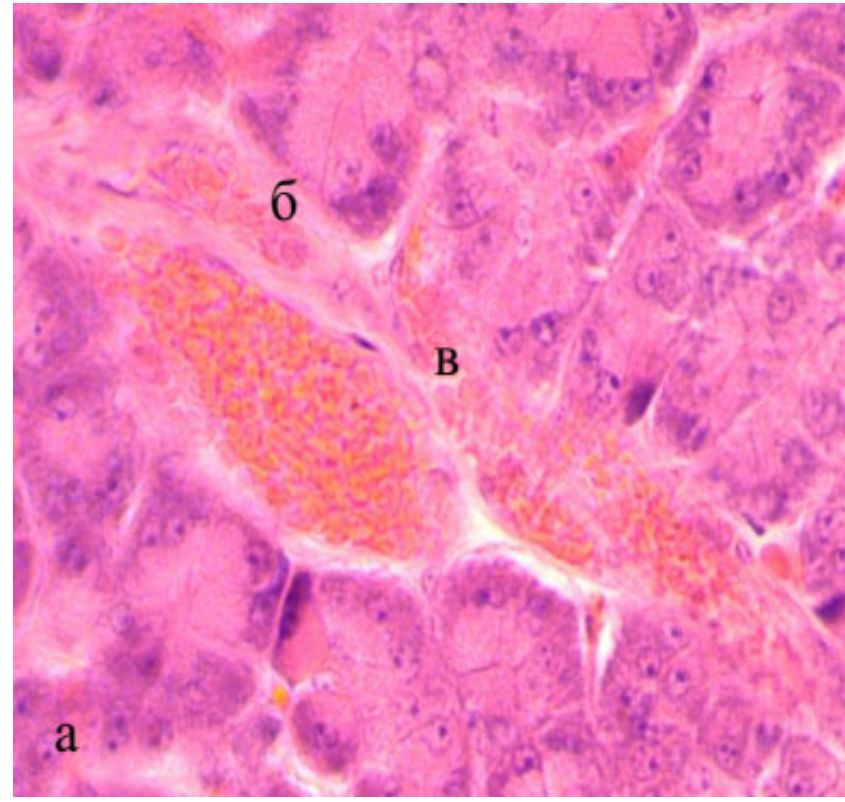

Рис. 3. Фрагмент мікроскопічної будови підшлункової залози котів за хронічного панкреатиту: a - екзокринна частина; б - міжацинарна сполучна тканина; в - крововиливи у міжацинарній сполучній тканині. Гематоксилін Караці та еозин. × 56

Кровоносні судини міжчасточкової сполучної тканини були переповненні кров'ю. У їхньому просвіті спостерігали стаз крові, що свідчило про порушення (припинення) у них кровообігу. Було виявлено підвищення проникності стінки судин гемомікроциркуляторного русла i, як наслідок, проникнення через їхні стінки, за межі судин, формених елементів та плазми крові з кровоносного русла у міжацинарну тканину (рис. 3) або ж у пухку волокнисту міжчасточкову сполучну тканину (рис. 4). Тому в пухкій волокнистій сполучній тканині виявляли поодинокі, невеликі за розмірами або ж великі крововиливи. Унаслідок плазморагії - виходу плазми із кровоносного русла та мукоїдного і фібриноїдного набухання - виявляли гіаліноз судин у міжчасточкової сполучної тканини. Стінки артерій були значно потовщеними, а самі су-

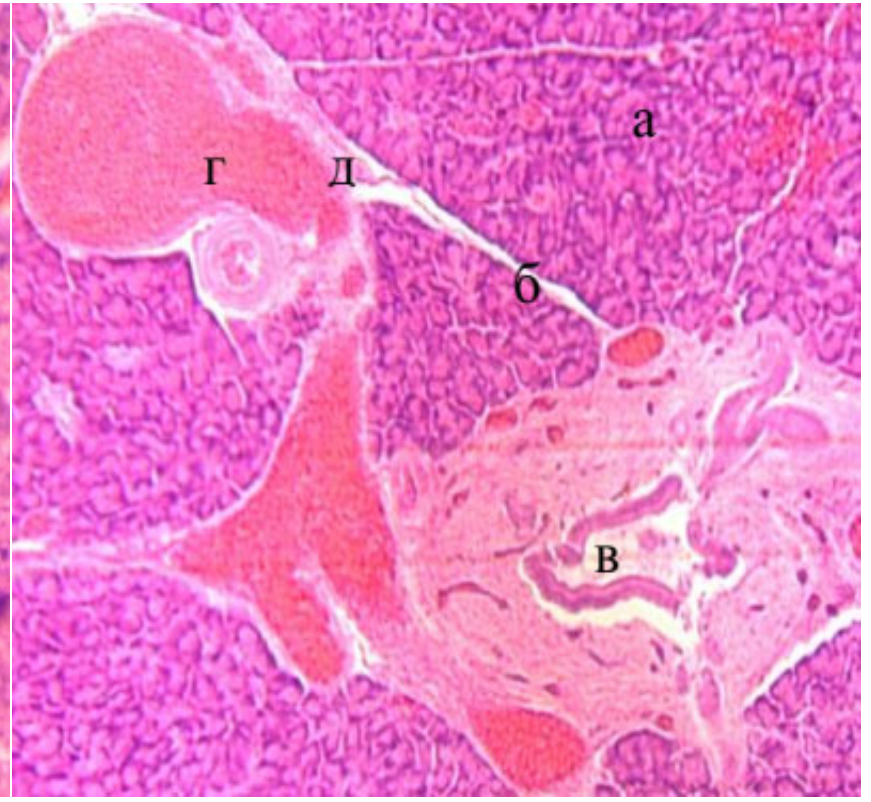

Рис. 4. Фрагмент мікроскопічної будови підшлункової залози котів за хронічного панкреатиту: а - екзокринна частина; б - міжчасточкова сполучна тканина; в - вивідна протока; г - судина переповнена кров'ю; д - ділянка порушення проникності судин та вихід крові у міжчасточкову сполучну тканину.

Гематоксилін Караці та еозин. × 56

дини на поперечному зрізі набували вигляду склоподібних трубочок із різко звуженим або облітерованим просвітом. Подібні зміни спостерігалися за хронічного панкреатиту у собак (Dubich, 2011). Також спостерігали повну деструкцію ацинусів, у деяких ацинарних клітинах залози виявляли дрібні або ж більш масивні вакуолі.

\section{Висновки}

Хронічний перебіг панкреатиту в котів характеризувався макро-, мікро- та органометричними змінами підшлункової залози. Абсолютна маса залози у тварин майже не змінювалася і становила 9,12 $\pm 2,03$ г. Відносна маса достовірно $(\mathrm{P} \leq 0,01)$ збільшилась у 1,34 раза і становила $0,51 \pm 0,08 \%$, порівнюючи 3 
контролем $0,38 \pm 0,06 \%$. За гістологічного дослідження встановлено порушення будови панкреатоцитів, виявлено дискомплексацію ацинусів екзокринної частини, ядра таких клітин перебували у стані каріолізису. На окремих ділянках гістопрепарату виявляли зменшення кількості панкреатичних острівців, останні були погано оконтуровані на тлі зруйнованої архітектоніки. У середині острівців Лангерганса виявляли зернисту дистрофію їх клітин-ендокриноцитів та вогнищеві крововиливи.

Перспективи подальших досліджень передбачають проведення гістохімічних досліджень паренхіми підшлункової залози котів у нормі та за хронічної форми панкреатиту.

Відомості про конфлікт інтересів. Автори стверджують про відсутність конфлікту інтересів щодо їх вкладу та результатів наукових досліджень.

\section{References}

Anderson, R., Wang, X. \& Ihse, I. (1995). The influence of abdominal sepsis on acute pancreatitis in rats, a study on mortality, permeability, arterial pressure and intestinal blood flow. Pancreas, 11(4), 365-373. doi: 10.1097/00006676-199511000-00008.

Berehovenko, I. M., \& Zinenko, D. Yu. (2008). Mikrotsyrkuliatorni y patomorfolohichni zminy u rozvytku eksperymentalnoho hostroho pankreatytu u shchuriv. Morfolohiia, 2(1), 33-38 (in Ukrainian).

Didenko, I. S. (2017). Zminy histolohichnoi struktury pidshlunkovoi zalozy za umov aloksanovoi hiperhlikemii u shchuriv u vikovomu aspekti [Changes in the histological structure of the pancreas under the conditions of alloxan hyperglycemia in rats in the age aspect]. Ukrainskyi zhurnal medytsyny, biolohii ta sportu, 6(8), 17-20. doi: 10.26693/jmbs02.06.017 (in Ukrainian).

Dubych, I. M. (2008). Histomorfolohiia ta orhanometrychni pokaznyky pidshlunkovoi zalozy tsutseniat [Histomorphology and organometric parameters of the pancreas of puppies]. Naukovyi visnyk Lvivskoho natsionalnoho universytetu veterynarnoi medytsyny ta biotekhnolohii im. S. Z. Hzhytskoho, 10(3), 73-76 (in Ukrainian).

Dubich, I. M. (2011). Morfolohiia pidshlunkovoi zalozy sobak v normi ta za pankreatytu [Morphology of the pancreas of dogs in normal and pancreatitis]. Avtoreferat dysertatsii kandydata veterynarnykh nauk. Kharkiv (in Ukrainian).

Filonenko, T. H., \& Klimov, A. O. (2009). Histolohichni zminy $\mathrm{v}$ pidshlunkovii zalozi $\mathrm{v}$ razi hostroho $\mathrm{y}$ khronichnoho pankreatytu $\mathrm{v}$ sobak [Histological changes in the pancreas in the case of acute and chronic pancreatitis in dogs]. Veterynarna medytsyna Ukrainy, 12, 27-28 (in Ukrainian).

Gushchin, Ya. I., Shedko, R. V., Muzhikyan, A. A., Makarova, M. N. \& Makarov, V. G. (2018). Sravnitelnaya morfologiya podzheludochnoy zhelezy eksperimentalnykh zhivotnykh i cheloveka [Comparative morphology of the pancreas in experimental ani- mals and humans]. Laboratornyye zhivotnyye dlya nauchnykh issledovaniy, 3, 33-48. doi: 10.29296/2618723X-2018-03-04 (in Russian).

Horalskyi, L. P. (Ed.) (2013). Pankreatyt sobak [Canine pancreatitis]. Polissia, Zhytomyr (in Ukrainian).

Horalskyi, L. P., Khomych, V. T. \& Kononskyi, O. I. (2019). Osnovy histolohichnoi tekhniky i morfofunktsionalni metody doslidzhennia u normi ta pry patolohii [Fundamentals of histological technique and morphofunctional research methods in normal and pathology]. Polissia, Zhytomyr (in Ukrainian).

Horalskyi, L. P., Kovalchuk, O. M., Gutyj, B. V. \& Sokulskyi, I. M. (2021). Pathomorphological features of the pancreas in mature cats with acute pancreatitis. Colloquium-Journal. Veterinary Science, 7(94), 8-9. doi: 10.24412/2520-6990-2021-794-7-12.

Horalskyi, L. P., Sokulskyi, I. M., \& Demus, N. V. (2016). Patomorfolohiia pidshlunkovoi zalozy sobak za khronichnoho pankreatytu [Pathomorphology of the pancreas of dogs with chronic pancreatitis]. Naukovyi visnyk LNUVMBT imeni S. Z. Gzhytskoho, 18(3), 40 43. doi: 10.15421/nvlvet7010 (in Ukrainian).

Katten, I. (2013). Sochetaniye pankreatita s kholangiogepatitom i vospalitelnym zabolevaniyem kishechnika (triadit) u koshek [Combination of pancreatitis with cholangiohepatitis and inflammatory bowel disease (triaditis) in cats]. Fokus, 23(2), 4-10 (in Russian).

Kravchenko, S. O., \& Bobrova, V. V. (2018). Ultrasonohrafichni zminy za hostrykh ta khronichnykh zapalen pidshlunkovoi zalozy u sviiskykh kotiv [Ultrasonographic changes in acute and chronic inflammation of the pancreas in domestic cats.]. Visnyk Poltavskoi derzhavnoi ahrarnoi akademii, 1, 138-142 (in Ukrainian).

Raraty, M. G. T., Finch, M., \& Neoptolemos, J. P. (1998). Acute Cholangitis and Pancreatitis Secondary to Common Duct Stones: Management Update. World Journal of Surgery, 22, 1155-1161. doi: 10.1007/s002689900535.

Raraty, Mg., Connor, S., Criddle, D. N., Suttonm, R., \& Neoptolemos, J. (2004). Acute pancreatitis and organ failure: Pathophysiology, natural history, and management strategies. Current Gastroenterology Reports, 6, 99-103. doi: 10.1007/s11894-004-0035-0.

Tuboltseva, N. V., \& Zhukov, V. M. (2018). Organopatologiya podzheludochnoy zhelezy koshek [Organopathology of the pancreas of cats]. Vestnik Altayskogo gosudarstvennogo agrarnogo universiteta, 9(167), 25-31 (in Russian).

Tymoshenko, O. P. (2007). Informatyvnist sonohrafichnoho doslidzhennia $u$ diahnostytsi zakhvoriuvan pidshlunkovoi zalozy sobak [Informativeness of sonographic research in the diagnosis of diseases of the pancreas of dogs]. Visnyk Bilotserkivskoho derzhavnoho ahrarnoho universytetu, 44, 101-103 (in Ukrainian).

Tymoshenko, O. P., \& Busel, Yu. M. (2009). Efektyvnist kompleksnoi diahnostyky pankreatytu v sobak, pidtverdzhena morfolohichnymy doslidzhenniamy [The effectiveness of a comprehensive diagnosis of pancreatitis in dogs, confirmed by morphological studies]. Visnyk Poltavskoi derzhavnoi ahrarnoi akademii, 1, 87-93 (in Ukrainian). 
Vasilyev, A. A., \& Urazayev, D. N. (2009). Izucheniye vliyaniya oktreotida na pankreaticheskuyu sekretsiyu pri ostrom pankreatite [Study of the effect of octreotide on pancreatic secretion in acute pancreatitis] Materialy Vserossiyskogo syezda veterinarnykh farmakologov i toksikologov "Effektivnyye i bezopasnyye lekarstvennyye sredstva v veterinarii” (pp. 15-16). Sankt-Peterburg (in Russian).

Westermarck, E., \& Wiberg, M. (2003). Exocrine pancreatic insufficiency in dogs. Vet. Clin. Noth. Am. Small Anim. Pract, 33(5), 1165-1179. doi: 10.1016/s01955616(03)00057-3.

Xenoulis, P. G. (2015). Diagnosis of pancreatitis in dogs and cats. J Small Anim. Pract, 56(1), 13-26. doi: 10.1111 jsap. 12274 .

Zinenko, D. Yu., \& Tverdokhlib, I. V. (2017). U1trastrukturni zminy hemomikrotsyrkuliatsii ta parenkhimy pidshlunkovoi zalozy pry rozvytku eksperymentalnoho hostroho pankreatytu u shchuriv
[Ultrastructural changes in hemomicrocirculation and pancreatic parenchyma in the development of experimental acute pancreatitis in rats]. Svit medytsyny ta biolohii, 3(61), 114-115. doi: 10.26724/2079-83342017-3-61-114-119 (in Ukrainian).

Zinenko, D. Yu., \& Tverdokhlib, I. V. (2020). Ultrastrukturna kharakterystyka hemomikrotsyrkuliatornoho rusla ta parenkhimatoznostromalnykh elementiv pidshlunkovoi zalozy ta pechinky $\mathrm{v}$ modeli hostroho pankreatytu z vykorystanniam riznykh doz taurokholatu natriiu [Ultrastructural characteristics of the hemomicrocirculatory tract and parenchymatous stromal elements of the pancreas and liver in a model of acute pancreatitis using different doses of sodium taurocholate]. Morphologia, 14(1), 23-25. doi: 10.26641/19979665.2020.1.23-34 (in Ukrainian).

Zon, H. A., Skrypka, M. V., \& Ivanovska, L. B. (2009). Patolohoanatomichnyi roztyn tvaryn [Pathological autopsy of animals]. Hlazunov R. O., Donetsk (in Ukrainian). 